\title{
PENGARUH DUKUNGAN SOSIAL TERHADAP KECEMASAN KARYAWAN AKIBAT COVID-19 PADA CV. CITRA JAYA BANJARBARU
}

\author{
Meiske Kristin Lumanauw \\ Sekolah Tinggi Ilmu Ekonomi Pancasetia \\ Jl. Ahmad Yani Km. 5.5 Banjarmasin \\ meiskelumanauw24@gmail.com
}

\begin{abstract}
ABSTRAK
Tujuan dari penelitian ini adalah: (1) Untuk menganalisis hubungan dukungan sosial terhadap kecemasan karyawan akibat Covid-19 pada CV. Citra Jaya Banjarbaru; dan (2) Untuk menganalisis pengaruh dukungan sosial terhadap kecemasan karyawan akibat Covid-19 pada CV. Citra Jaya Banjarbaru. Metode penelitian yang digunakan merupakan metode penelitian kuantitatif. Populasi dalam penelitian ini adalah seluruh karyawan CV. Citra Jaya Banjarbaru yang berjumlah 41 orang. Mengingat jumlah populasi relatif kecil, yaitu di bawah 100, maka seluruh anggota populasi diambil semua sebagai sampel penelitian. Teknik analisis data yang digunakan dalam penelitian ini menggunakan analisis korelasi product moment pearson dan analisis regresi. Hasil penelitian menunjukkan bahwa (1) Ada hubungan antara dukungan sosial dengan kecemasan menghadapi Covid-19; dan (2) Dukungan sosial perpengaruh negatif dan signifikan terhadap kecemasan menghadapi Covid-19. Berpengaruh negatif dan signifikan artinya jika dukungan sosial meningkat, maka akan menyebabkan kecemasan menghadapi Covid-19 akan menurun. Variabel kecemasan menghadapi Covid-19 dijelaskan oleh variabel dukungan sosial sebesar $43,7 \%$, sedangkan sisanya $56,3 \%$ dijelaskan oleh sebab-sebab yang lain di luar model.
\end{abstract}

Kata Kunci: Dukungan Sosial, Kecemasan, Covid-19.

\section{ABSTRACT}

The objectives of this study were: (1) To analyze the relationship between social support and employee anxiety due to Covid-19 at CV. Citra Jaya Banjarbaru; and (2) To analyze the effect of social support and employee anxiety due to Covid-19 at CV. Citra Jaya Banjarbaru. The research method used is a quantitative research method. The population in this study were all employees of CV. Citra Jaya Banjarbaru, amounting to 41 people. Considering the relatively small population, which is below 100, all members of the population are taken as the research sample. The data analysis technique used in this study used Pearson product moment correlation analysis and regression analysis. The results showed that (1) there was a relationship between social support and anxiety in facing Covid-19; and (2) Social support has a negative and significant effect on anxiety in facing Covid-19. It has a negative and significant effect, meaning that if social support increases, it will cause anxiety to face Covid19 to decrease. The variable of anxiety facing Covid-19 is explained by the social support variable of $43.7 \%$, while the remaining $56.3 \%$ is explained by other causes outside the model.

Keywords: Social Support, Anxiety, Covid-19. 


\section{A. Latar Belakang Masalah}

Pandemi Covid-19 yang dimulai pada akhir tahun 2019 telah menebarkan kecemasan di setiap orang, tidak terkecuali pada para pekerja. Corona Virus Disease pada tahun 2019 (Covid-19) telah menjadi pandemic global semenjak diumumkan oleh WHO pada tanggal 11 Maret 2020. Covid-19 pertama kali muncul di Wuhan China pada akhir tahun 2019. Kemudian berkembang dengan cepat dan tidak terkontrol ke seluruh dunia. Tercatat sudah lebih 213 negara yang terkonfirmasi terinfeksi Covid-19 (Syafrida dan Hartati, 2020; Xiao et al., 2020).

Kasus Covid-19 di Indonesia pertama muncul pada tanggal 2 Maret 2020 dan sampai tanggal 31 Agustus 2020 datanya dapat dikemukakan sebagai berikut:

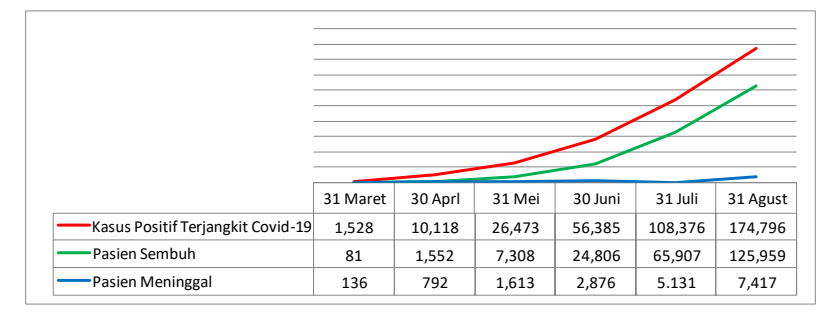

Sumber: covid19.go.id

Gambar 1. Grafik Perkembangan Kasus

Covid-19 Tanggal 31 Maret sampai dengan

31 Agustus 2020 di Indonesia

Berdasarkan data di atas dapat dilihat bahwa kasus positif terjangkit Covid-19 di Indonesia dari bulan Maret 2020 sampai dengan bulan Agustus 2020 terus mengalami peningkatan. Begitu juga dengan pasien sembuh, dari bulan Maret 2020 sampai dengan bulan Agustus 2020 juga terus mengalami peningkatan. Namun kasus meninggal dunia akibat Covid-19 juga mengalami peningkatan dari bulan Maret 2020 sampai dengan Bulan Agustus 2020.

Mengingat Covid-19 merupakan virus yang berbahaya dan mematikan, dalam situasi sekarang orang akan lebih mudah cemas dan merasa lelah karena Covid-19, terlebih-lebih bagi orang yang bekerja di rumah sakit (Abro et al., 2015; Garcia-Herrero et al., 2017). Peningkatan kecemasan ini mengakibatkan penurunan motivasi dalam bekerja. Kecemasan mendorong manusia untuk mencari bantuan dan dukungan sosialisasi masyaarakat di sekitarnya (Putra dan Susilawati, 2018; Adnyaswari dan Adnyani, 2017).

Hasil penelitian Wang et al. (2020) yang melibatkan 1.210 responden dari 194 kota di Cina. Secara total, 53,8\% responden menilai dampak psikologis dari wabah tersebut sedang atau berat; $16,5 \%$ melaporkan gejala depresi sedang hingga berat; $28,8 \%$ melaporkan gejala kecemasan sedang hingga berat; dan $8,1 \%$ melaporkan tingkat stres sedang hingga berat. Hasil penelitian tersebut juga menunjukan bahwa perempauan, lebih rentan terkena stress, cemas dan depresi. Hal senada dengan penelitian $\mathrm{Li}$ et al. (2020) pada 17,865 pengguna aktif Weibo dengan model machine learning. menunjukkan bahwa terjadi peningkatan emosi negatif (cemas, stress) dan penilaian risiko, sementara emosi positif (kebahagiaan, kepuasan hidup) mengalami penurunan. Sementara di indonesia, hasil survei Iskandarsyah dan Yudiana (2020) menunjukkan $78 \%$ partisipan cemas dengan penyebaran COVID-19 dan 23\% merasa tidak bahagia atau dalam kondisi tertekan.

Fenomena kecemasan menghadapi Covid-19 seperti tersebut di atas juga terjadi di CV. Citra Jaya Banjarbaru. Hal ini ditunjukkan pada bulan Maret 2020 setelah diumumkan oleh pemerintah adanya Covid-19 di Indonesia, absensi karyawan di CV. Citra Jaya Banjarbaru menunjukkan ketidakhadiran hingga lebih dari $90 \%$. Dari 41 karyawan yang terdiri dari dari 30 (tiga puluh) karyawan tetap dan 11 (sebelas) karyawan kontrak, pada bulan Maret 2020 hanya hadir 3 (tiga) orang yang berarti 38 karyawan tidak hadir di kantor. Data berikut menunjukkan ketidakhadiran karyawan CV. Citra Jaya Banjarbaru dari bulan Januari 2020 sampai dengan bulan Agustus 2020. 
Tabel 1

Data Ketidakhadiran karyawan CV. Citra Jaya Banjarbaru dari Bulan Januari 2020 sampai dengan Bulan Agustus 2020

\begin{tabular}{|c|c|c|c|c|}
\hline No & Bulan & $\begin{array}{c}\text { Jumlah } \\
\text { Karyawan } \\
\text { (Orang) }\end{array}$ & $\begin{array}{c}\text { Ketidakhadiran } \\
\text { (Orang) }\end{array}$ & $\begin{array}{c}\text { \% } \\
\text { Ketidakhadiran }\end{array}$ \\
\hline 1 & $\begin{array}{c}\text { Januari } \\
2020\end{array}$ & 41 & 3 & 7,32 \\
\hline 2 & $\begin{array}{c}\text { Februari } \\
2020\end{array}$ & 41 & 2 & 4,88 \\
\hline 3 & $\begin{array}{c}\text { Maret } \\
2020\end{array}$ & 41 & 38 & 92,68 \\
\hline 4 & $\begin{array}{c}\text { April } \\
2020\end{array}$ & 41 & 35 & 85,37 \\
\hline 5 & $\begin{array}{c}\text { Mei } \\
2020\end{array}$ & 41 & 30 & 73,17 \\
\hline 6 & $\begin{array}{c}\text { Juni } \\
2020\end{array}$ & 41 & 18 & 43,90 \\
\hline 7 & $\begin{array}{c}\text { Juli } \\
2020\end{array}$ & 41 & 9 & 21,95 \\
\hline 8 & $\begin{array}{c}\text { Agustus } \\
2020\end{array}$ & 41 & 6 & 14,63 \\
\hline
\end{tabular}

Sumber: Data CV. Citra Jaya Banjarbaru, 2020

Berdasarkan tabel tersebut di atas, dapat dilihat bahwa karyawan CV. Citra Jaya Banjarbaru pada bulan Januari 2020 yang tidak hadir hanya 3 orang atau 7,32\% dan bulan Februari 2020 hanya 2 orang atau 4,88. Namun pada bulan Maret 2020 karyawan CV. Citra Jaya Banjarbaru yang tidak hadir melonjak drastis menjadi 38 orang atau 92,68\%, hal ini terjadi karena setelah diumumkan oleh pemerintah bahwa Covid-19 sudah masuk di Indonesia. Pada bulan April juga masih banyak karyawan CV. Citra Jaya Banjarbaru yang tidak hadir yaitu 35 karyawan atau $85,37 \%$ dan bulan Mei 2020 sebanyak 30 karyawan 73,17\% yang tidak hadir. Setelah diberlakukannya New Normal pada bulan Juni 2020, sudah banyak karyawan yang hadir untuk bekerja di CV. Citra Jaya Banjarbaru, karyawan yang tidak hadir di bulan Juni 2020 menurun menjadi 18 karyawan atau $43,90 \%$, dan bulan Juli yang tidak hadir mengalami penurunan lagi menjadi 9 karyawan atau 21,98\%. Begitu juga pada bulan Agustus 2020, jumlah karyawan yang tidak hadir hanya 6 orang saja atau $14,63 \%$.

Untuk mengatasi rasa cemas ini, para karyawan CV. Citra Jaya Banjarbaru membutuhkan dukungan dari keluarga dan teman-temannya. Adanya dukungan tersebut akan membuat karyawan merasa lebih tentram dan lega sehingga dapat menurunkan kecemasan. Xiao et al. (2020) mendefinisikan dukungan sosial sebagai salah satu fungsi pertalian sosial yang menggambarkan tingkat dan kualitas umum dari hubungan interpersonal yang akan melindungi individu dari konsekuensi cemas bahkan stres.

Nahum-Shani et al. (2015) dan Stapleton et al. (2015) menyatakan bahwa dukungan sosial dapat menurunkan kecemasan karyawan sehingga motivasi kerja dapat ditingkatkan kembali. Selain itu menurut Chou (2015) dan Iswanto dan Agustin (2016) dukungan sosial yang diberikan oleh orang terdekat (significant others) berupa perhatian, emosi, bantuan instrumental, pemberian informasi dan penilaian diri terhadap individu dalam mengahadapi bahaya Covid 19 dapat mengubah presepsi kecemasan dan ketakutan serta kekhawatiran individu tersebut dalam bekerja pada saat pandemi ini.

\section{B. Rumusan Masalah}

Berdasarkan latar belakang yang telah diuraikan, maka permasalahan yang akan dibahas dalam penelitian dirumuskan dalam bentuk pertanyaan penelitian sebagai berikut:

1. Bagaimana hubungan dukungan sosial dan kecemasan karyawan akibat Covid-19 pada CV. Citra Jaya Banjarbaru?

2. Bagaimana pengaruh dukungan sosial untuk menurunkan kecemasan karyawan akibat Covid19 pada CV. Citra Jaya Banjarbaru?

\section{Landasan Teori}

\section{Dukungan Sosial}

Definisi dukungaan sosial oleh Nichols dan Jenkinson (2015) adalah: "...as the presence of others, or the resources provide by them, prior to, during and following a stressful event" (Terjemahan bebas: dukungan sosial itu hadir bersama kehadiran 
orang lain atau hadirnya sumberdaya yang mereka sediakan baik sebelum, pada saat atau setelah individu mengalami situasi tertekan). Zimet et al. (2014) menyatakan bahwa dukungan sosial sebagai diterimanya dukungan yang diberikan oleh orang-orang terdekat individu meliputi dukungan keluarga, dukungan pertemanan dan dukungan dari orang-orang yang berarti disekitar individu.

Johnson dan Johnson (2015) mendefisinikan dukungan sosial sebagai keberadaan orang lain yang bisa diandalkan untuk dimintai bantuan, dorongan dan penerimaan apabila individu mengalami kesulitan. Menurut Sears dan Freedman (2017) dukungan sosial adalah suatu hubungan interpersonal dimana individu memberikan bantuan berupa empati, motivasi, penyediaan informasi dan penghargaan atau penilaian terhadap individu. Dukungan sosial yang diberikan seseorang kepada orang lain akan memberikan kekuatan dan rasa percaya sehingga menimbulkan keyakinan dalam diri seseorang untuk melakukan suatu tindakan.

Berdasarkan pengertian dukungan sosial yang dikemukakan oleh para ahli tersebut di atas, dapat disimpulkan bahwa dukungan sosial adalah sumber-sumber inspiratif dalam pemberian dukungan serta mampu memberikan rasa nyaman, ketenangan maupun suatu perubahan pada diri seseorang tersebut adalah tak lain orang-orang terdekat, seperti orang tua, keluarga, guru, sahabat, kekasih, dan kelompok masyarakat. Karena setiap individu memerlukan sebuah dukungan baik secara moril, material maupun sosial untuk bisa memotivasi diri individu, menjadi lebih baik dari sebelumnya. Dukungan sosial tersebut berguna dalam mengatasi situasi stressful menjadi situasi yang aman dan nyaman. Kenyamanan terjadi karena individu merasa dipedulikan, dihargai dan didukung oleh orang lain (significant others) sebagai bagian dari social network yang saling membantu untuk kesejehteraan bersama.

\section{Kecemasan}

Spielberger

mendefinisikan kecemasan adalah reaksi emosional yang tidak menyenangkan terhadap bahaya nyata atau imaginer yang disertai dengan perubahan pada sistem saraf otonom dan pengalaman subjektif sebagai tekanan, ketakutan dan kegelisahan. Selanjutnya dijelaskan bahwa konsep ancaman yaitu penilaian dari orang lain yang bersifat negatif sehingga mengancam diri individu tersebut. Kecemasan juga merupakan keadaan yang mana pola tingkah laku direpresentasikan dengan keadaan emosional yang dihasilkan dari pikiran-pikiran dan perasaan yang tidak menyenangkan (Purnamarini, Setiawan dan Hidayat, 2016)

Calhoun dan Acocella (2015) menyatakan kecemasan adalah ketakutan yang tidak nyata, suatu perasaan terancam sebagai tanggapan terhadap sesuatu yang sebenarnya tidak mengancam. Dalam arti tradisional, menurut Ollendick istilah kecemasan menunjuk kepada keadaan emosi yang menentang atau tidak menyenangkan yang meliputi interpretasi subyektif dan arousal atau rangsangan fisiologis (Linda De Clarq, 2017). Menurut Edelmann (2016), kecemasan adalah:

"Anxiety is a personality characteristic of responding to certain situations with a stress syndrome of response. Anxiety 
states are then a function of the situations that evoke them and the individual personality that is prone to stress" (Kecemasan adalah suatu karakteristik kepribadian dalam menjawab ke situasi tertentu dengan suatu sindrom/gejala respon stres/tekanan. Kemudian kondisi kecemasan adalah suatu fungsi dari situasi membangkitkan/menstimulir yang kepada kecemasan dan kepribadian individu yang cenderung tertekan".

Rosenberg dan Caplan (2016) menyebutkan kecemasan merupakan keadaan dimana seseorang mengalami perasaan gelisah atau cemas dan aktivitas sistem saraf otonom dalam merespon sesuatu ancaman yang tidak jelas dan tidak spesifik.

Berdasarkan definisi kecemasan yang dikemukakan para ahli tersebut di atas, maka dapat disimpulkan kecemasan adalah suatu bentuk emosi yang tidak dapat dikontrol oleh diri individu sehingga membuat individu tersebut tidak nyaman, meruakan pengalaman yang samar dan merasa memiliki ketidakmampuan yang irasional. Dengan demikian kecemasan merupakan rasa takut atau khawatir pada situasi tertentu yang sangat mengancam yang dapat menyebabkan kegelisahan karena adanya ketidakpastian di masa mendatang serta ketakutan bahwa sesuatu yang buruk akan terjadi.

\section{Kerangka Pemikiran}

Di dalam situasi pandemi Covid-19 orang akan lebih mudah cemas dan merasa penat karena Covid-19 tidak hanya berdampak kesehatan tetapi juga kepada ekonomi dan timbulnya gesekan di lingkungan rumah akibat dampak kebijakan social and physical distancing dan work from home (WFH). Karyawan lebih mudah cemas untuk pergi bekerja karena cemas tertular virus Covid-19 (Hamouche, 2020).

Dukungan sosial diperlukan dalam situasi pandemi Covid-19 seperti saat ini terhadap karyawan yang harus tetap bekerja untuk menghidupi keluarganya. Terdapat 4 (empat) jenis dukungan sosial, yang pertama ada appraisal support adalah dukungan yang bisa diberikan untuk memecahkan masalah atau menguraikan stressor. Salah satunya adalah dengan menjadi teman yang bisa mendengar. Dukungan sosial yang kedua adalah tangible support atau bantuan nyata yang dapat menyelesaikan masalah. Dalam keadaan saat ini, bantuan bisa berupa makanan, masker atau barang-barang yang dibutuhkan teman dan tetangga yang membutuhkan. Bentuk dukungan sosial yang ketiga adalah self esteem support yaitu dukungan untuk bisa membuat seseorang memiliki harga diri atau pandangan diri yang lebih baik tentang dirinya. Dukungan sosial yang keempat adalah belonging support itu menjadi diterima dalam satu bagian atau satu kelompok (Hamouche, 2020).

Berdasarkan uraian tersebut di atas, maka kerangka pemikiran dalam penelitian ini dapat digambarkan sebaggai berikut:

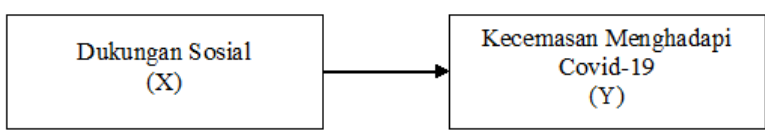

Gambar 2. Kerangka Pemikiran

\section{E. Hipotesis Penelitian}

Berdasarkan rumusan masalah, landasan teori dan kerangka pemikiran yang telah dipaparkan, maka hipotesis penelitian dapat dirumuskan sebagai berikut:

$\begin{array}{rlr}\mathrm{H}_{1}: & \begin{array}{l}\text { Dukungan sosial } \\ \text { hubungan dengan } \\ \text { menghadapi Covid-19. }\end{array} & \text { kecemasan } \\ & \end{array}$

$\mathrm{H}_{2}$ : Dukungan sosial bepengaruh negatif dan signifikan terhadap kecemasan menghadapi Covid-19.

\section{F. Metode Penelitian}

\section{Jenis Penelitian}

Secara umum tujuan
penelitian ini adalah untuk


membuktikan dan menganalisis pengaruh variabel independen dukungan sosial terhadap variabel dependen kecemasan menghadapi Codi-19.

Berdasarkan tujuan penelitian tersebut, maka penelitian ini termasuk jenis penelitian penjelasan atau explanatory research (Sugiyono, 2017: 98), yang akan menjelaskan hubungan kausal antara variabel independen tersebut terhadap variabel dependen melalui pengujian hipotesis (Sekaran, 2013: 318).

\section{Populasi dan Sampel Penelitian}

Populasi penelitian adalah karyawan CV. Citra Jaya Banjarbaru yang berjumlah 41 karyawan yang terdiri dari dari 30 (tiga puluh) karyawan tetap dan 11 (sebelas) karyawan kontrak. Menurut Sugiyono (2017: 116), sampel adalah bagian dari jumlah dan karakteristik yang dimiliki oleh populasi. Mengingat jumlah populasi relatif kecil yaitu 41 orang, maka semua populasi diambil menjadi sampel. Penelitian yang menjadikan seluruh populasi sebagai sampel disebut penelitian populasi atau penelitian sensus (Sugiyono, 2017: 116).

\section{Definisi Operasional Variabel Penelitian}

\section{a. Dukungan Sosial}

Dukungan sosial adalah keberadaan, kesediaan, kepedulian dari orang lain yang dapat diandalkan, menghargai dan menyayangi kita. Selain itu dukungan sosial yang diberikan oleh orang terdekat (significant others) berupa perhatian, emosi, bantuan instrumental, pemberian informasi dan penilaian diri kepada individu yang menghadapi masa pensiun dapat mengubah presepsi kecemasan dan ketakutan serta kekhawatiran individu tersebut dalam menghadapi masa pensiun (Sarafino, 2015). Indikatornya adalah:

1) Dukungan dari keluarga untuk tetap bekerja

2) Dukungan dari pemilik perusahaan untuk tetap bekerja

3) Dukungan dari atasan untuk tetap bekerja

4) Dukungan dari rekan kerja untuk tetap bekerja

5) Dukungan dari masyarakat untuk tetap bekerja

6) Mendapat bimbingan mengenai protokol kesehatan agar tetap aman dalam bekerja

7) Mendapat kesempatan untuk bekerja atau tidak diPHK

\section{b. Kecemasan}

Kecemasan merupakan keadaan dimana seseorang mengalami perasaan gelisah atau cemas dan aktivitas sistem saraf otonom dalam merespon sesuatu ancaman yang tidak jelas dan tidak spesifik (Rosenberg dan Caplan, 2016). Menurut Nevid et al. (2018), anxietas/kecemasan adalah suatu keadaan aprehensi atau keadaan khawatir yang mengeluhkan bahwa sesuatu yang buruk akan terjadi. Kecemasan merupakan respon yang tepat terhadap ancaman, tetapi kecemasan dapat menjadi abnormal apabila tingkatannya tidak sesuai dengan porsi ancamannya ataupun datang tanpa adanya sebab tertentu. Indikatornya adalah:

1) Takut memprediksi masa depan pekerjaan

2) Merasa panik ketika keluar rumah untuk bekerja

3) Mudah merasa lelah dalam bekerja

4) Mengalami kesulitan tidur 
5) Mengalami kesulitan memusatkan pikiran

6) Selalu menghadapi keraguan dan ketakutan yang mengganggu

7) Kehilangan kepercayaan diri

\section{Teknik Analisis Data}

a. Analisis Deskriptif

Analisis deskriptif bertujuan untuk memberikan deskripsi mengenai objek penelitian berdasarkan data variabel yang diperoleh dan kelompok subjek yang diteliti. Tanggapan responden terhadap pernyataan diberikan nilai/skor. Skor yang diperoleh kemudian dipersentase skor dengan rumus sebagai berikut.

$$
\% S=\frac{S i}{S \max } \times 100 \%
$$

Keterangan:

$$
\begin{array}{ll}
\% \mathrm{~S} & =\text { Persentse Skor } \\
\mathrm{S} & =\text { Skor } \\
\text { Smax } & =\text { Skor Maksimal }
\end{array}
$$

Selanjutnya skor tersebut dikategorikan dan berpedoman pada tabel berikut.

Tabel 2

Pedoman Kategorisasi Variabel Penelitian

\begin{tabular}{|c|c|c|}
\hline Skor & $\begin{array}{c}\text { Persentase } \\
\text { Pencapaian } \\
\text { Skor }(\%)\end{array}$ & Kategori \\
\hline 5 & $>84-100$ & Sangat Baik \\
\hline 4 & $>68-84$ & Baik \\
\hline 3 & $>52-68$ & Sedang \\
\hline 2 & $>36-52$ & Tidak Baik \\
\hline 1 & $20-36$ & Sangat Tidak Baik \\
\hline
\end{tabular}

b. Uji Asumsi Klasik

Mengingat analisa data yang digunakan dalam penelitian ini adalah analisa model regresi, maka untuk menentukan ketepatan model perlu dilakukan pengujian atas beberapa asumsi klasik yang mendasari model regresi.
Teknik estimasi variabel dependen yang melandasi analisis regresi disebut Ordinary Least Squares (OLS). Model regresi yang menggunakan teknik OLS, sering disebut sebagai model regresi linear klasik. Untuk dapat dianalisis hasilnya, model tersebut harus menggunakan asumsi OLS. Terdapat 10 asumsi OLS yang harus dipenuhi, namun pada penelitian ini digunakan Uji Normalitas, Uji Autokorelasi, dan Uji Multikolinieritas. Pengujian ini dilakukan untuk meyakini bahwa model regresi yang diperoleh mempunyai kemampuan untuk memprediksi, dan kemanfaatan dalam pengambilan keputusan.

\section{c. Analisis Korelasi}

Untuk pembuktian hipotesis pertama $\left(\mathrm{H}_{1}\right)$ dilakukan dengan menggunakan metode atau teknik analisis korelasi product moment dari Karl Pearson.

\section{d. Analisis Regresi}

Untuk pembuktian hipotesis kedua $\left(\mathrm{H}_{2}\right)$ digunakan analisis regresi. Analisis regresi merupakan studi mengenai ketergantungan variabel dependen dengan salah satu atau lebih variabel independen, dengan tujuan untuk mengestimasi rata-rata populasi atau nilai rata-rata variabel dependen berdasarkan nilai variabel independen yang diketahui (Ghozali, 2012: 81). Hasil dari analisis regresi adalah berupa koefisien untuk masing-masing variabel independen. Dalam penelitian ini, variabel independennya adalah dukungan sosial (X). Sedangkan variabel dependennya adalah kecemasan menghadapi Covid-19 (Y), 
sehingga persamaan regresinya adalah sebagai berikut:

$$
\mathrm{Y}=\alpha+b . \mathrm{X}
$$

Keterangan :

$$
\begin{aligned}
\alpha & =\text { Nilai konstanta } \\
\mathrm{Y} & =\quad \text { Kecemasan } \\
& \text { Menghadapi Covid-19 } \\
\mathrm{b} & =\text { Koefisien regresi } \\
\mathrm{X} & =\text { Dukungan Sosial }
\end{aligned}
$$

\section{G. Hasil dan Pembahasan}

\section{Hasil Uji Validitas}

a. Hasil Uji Validitas Variabel Dukungan Sosial (X)

Hasil uji validitas pada variabel dukungan sosial (X) dapat dilihat pada tabel berikut:

Tabel 3

Uji Validitas Variabel

Dukungan Sosial

\begin{tabular}{|c|c|c|c|c|}
\hline No & Indikator & $\mathbf{r}_{\text {hitung }}$ & Kriteria & Validitas \\
\hline 1 & $\mathrm{X} 1$ & 0,681 & 0,30 & Valid \\
\hline 2 & $\mathrm{X} 2$ & 0,748 & 0,30 & Valid \\
\hline 3 & $\mathrm{X} 3$ & 0,578 & 0,30 & Valid \\
\hline 4 & $\mathrm{X} 4$ & 0,717 & 0,30 & Valid \\
\hline 5 & $\mathrm{X} 5$ & 0,511 & 0,30 & Valid \\
\hline 6 & $\mathrm{X} 6$ & 0,532 & 0,30 & Valid \\
\hline 7 & $\mathrm{X} 7$ & 0,557 & 0,30 & Valid \\
\hline
\end{tabular}

Berdasarkan Tabel 3 di atas terlihat bahwa dukungan sosial mempunyai $\mathrm{r}_{\text {hitung }}$ lebih besar dari kriteria variabel dengan demikian seluruh indikator tersebut dapat dinyatakan valid. Hal ini sependapat dengan Ghozali, (2012 : 45), suatu instrumen dikatakan valid jika pertanyaan pada instrumen mampu untuk mengungkap sesuatu yang akan diukur oleh instrumen tersebut. Uji Validitas dihitung dengan membandingkan nilai $\mathrm{r}$ hitung (correlated item-total correlation) dengan nilai kriteria variabel. Jika $r$ hitung lebih besar kriteria variabel yang menurut Gozali (2012:47) kriteria variabel adalah 0,30 , maka pernyataan/pertanyaan dalam kuesioner dinyatakan valid.

\section{b. Hasil Uji Validitas Variabel}

\section{Kecemasan Covid-19 (Y) \\ Menghadapi \\ Hasil uji validitas pada variabel kecemasan menghadapi Covid-19 (Y) dapat dilihat pada tabel berikut:}

Tabel 4

Uji Validitas Variabel Kecemasan Menghadapi Covid-19

\begin{tabular}{|c|cc|c|c|c|}
\hline No & \multicolumn{2}{|c|}{ Indikator } & rhitung & Kriteria & Validitas \\
\hline 1 & $\&$ & Y1 & 0,368 & 0,30 & Valid \\
\hline 2 & $\mathbf{r}$ & Y2 & 0,756 & 0,30 & Valid \\
\hline 3 & $\mathrm{~d}$ & $\mathrm{Y} 3$ & 0,669 & 0,30 & Valid \\
\hline 4 & $\mathrm{Y} 4$ & 0,755 & 0,30 & Valid \\
\hline 5 & $\mathrm{Y} 5$ & 0,693 & 0,30 & Valid \\
\hline 6 & $\mathrm{Y} 6$ & 0,708 & 0,30 & Valid \\
\hline 7 & $\mathbf{q}$ & Y7 & 0,700 & 0,30 & Valid \\
\hline
\end{tabular}

kan Tabel 4 di atas terlihat bahwa kecemasan menghadapi Covid-19 mempunyai rhitung lebih besar dari kriteria variabel dengan demikian seluruh indikator tersebut dapat dinyatakan valid. Hal ini sependapat dengan Ghozali, (2012 : 45), suatu instrumen dikatakan valid jika pertanyaan pada instrumen mampu untuk mengungkap sesuatu yang akan diukur oleh instrumen tersebut. Uji Validitas dihitung dengan membandingkan nilai $\mathrm{r}$ hitung (correlated item-total correlation) dengan nilai kriteria variabel. Jika $r$ hitung lebih besar kriteria variabel yang menurut Gozali (2012:47) kriteria variabel adalah 0,30 , maka pernyataan/pertanyaan dalam kuesioner dinyatakan vailid.

\section{Hasil Uji Reliabilitas}

Hasil uji realibilitas dengan menggunakan SPSS ver 21 for windows terlihat hasil seperti Tabel 5 sebagai berikut. 
Tabel 5

Hasil Uji Realibilitas

\begin{tabular}{|c|l|c|c|c|}
\hline No & Variabel & $\begin{array}{c}\text { Cronbac } \\
\text { h's } \\
\text { Alpha }\end{array}$ & $\begin{array}{c}\text { Nilai } \\
\text { kritis/ } \\
\text { Stand } \\
\text { ard }\end{array}$ & $\begin{array}{c}\text { Reliabi } \\
\text { litas }\end{array}$ \\
\hline 1 & Dukungan Sosial & 0,691 & \multirow{2}{*}{$>0,6$} & $\begin{array}{c}\text { Reliabe } \\
1\end{array}$ \\
\hline 2 & $\begin{array}{l}\text { Kecemasan } \\
\text { Menghadapi } \\
\text { Covid-19 }\end{array}$ & 0,792 & & \\
\hline
\end{tabular}

Berdasarkan ringkasan hasil uji reliabilitas seperti yang terangkum dalam Tabel 5 di atas, dapat diketahui bahwa nilai koefisien Cronbach Alpha untuk seluruh variabel nilainya lebih besar dari nilai kritis/standard sebesar 0,6, maka dapat dikatakan bahwa semua butir pertanyaan dalam variabel penelitian ini adalah reliabel. Menurut kriteria Nunally dalam Ghozali (2012) hal tersebut dapat dikatakan Reliabel. Sehingga butir-butir pernyataan/pertanyaan dalam kuesioner dapat digunakan untuk penelitian selanjutnya.

\section{Hasil Analisis Deskriptif}

\section{a. Hasil Analisis Deskriptif Variabel Dukungan Sosial (X)}

Frekuensi jawaban responden dari kuesioner variabel dukungan sosial beserta skor dari jawaban variabel dukungan sosial tersebut dapat dilihat sebagai berikut:

\section{Tabel 6}

Hasil Analisis Deskriptif Variabel

Dukungan Sosial

\begin{tabular}{|c|c|c|c|c|c|c|}
\hline \multirow{2}{*}{ No. } & \multicolumn{7}{|c|}{ Frekuensi Jawaban } & \multirow{2}{*}{ Jumlah } \\
\cline { 2 - 6 } & $\mathbf{1}$ & $\mathbf{2}$ & $\mathbf{3}$ & $\mathbf{4}$ & $\mathbf{5}$ & \\
\hline X1 & 0 & 4 & 4 & 26 & 7 & 41 \\
\hline X2 & 1 & 8 & 4 & 16 & 12 & 41 \\
\hline X3 & 2 & 5 & 9 & 16 & 9 & 41 \\
\hline X4 & 1 & 6 & 8 & 16 & 10 & 41 \\
\hline X5 & 1 & 6 & 10 & 20 & 4 & 41 \\
\hline X6 & 1 & 6 & 7 & 23 & 4 & 41 \\
\hline X7 & 0 & 1 & 12 & 26 & 2 & 41 \\
\hline Jumlah & $\mathbf{6}$ & $\mathbf{3 6}$ & $\mathbf{5 4}$ & $\mathbf{1 4 3}$ & $\mathbf{4 8}$ & $\mathbf{2 8 7}$ \\
\hline No. & $\mathbf{7}$ & $\mathbf{2}$ & $\mathbf{3}$ & $\mathbf{4}$ & $\mathbf{5}$ & \\
\cline { 2 - 6 } & $\mathbf{1}$ & $\mathbf{2}$ (T) & (T) & \\
\hline & (STS) & (TS) & (RR) & (S) & (SS) & \\
\hline X1 & 0 & 8 & 12 & 104 & 35 & 159 \\
\hline X2 & 1 & 16 & 12 & 64 & 60 & 153 \\
\hline X3 & 2 & 10 & 27 & 64 & 45 & 148 \\
\hline X4 & 1 & 12 & 24 & 64 & 50 & 151 \\
\hline X5 & 1 & 12 & 30 & 80 & 20 & 143 \\
\hline
\end{tabular}

\begin{tabular}{|c|c|c|c|c|c|c|}
$\mathrm{X} 6$ & 1 & 12 & 21 & 92 & 20 & 146 \\
\hline $\mathrm{X} 7$ & 0 & 2 & 36 & 104 & 10 & 152 \\
\hline Jumlah & $\mathbf{6}$ & $\mathbf{7 2}$ & $\mathbf{1 6 2}$ & $\mathbf{5 7 2}$ & $\mathbf{2 4 0}$ & $\mathbf{1 0 5 2}$ \\
\hline
\end{tabular}

Catatan: STS = Sangat Tidak Setuju; TS = Tidak Setuju; $\mathrm{RR}=$ Ragu Ragu $\mathrm{S}=$ Setuju; SS = Sangat Setuju

Skor jawaban diperoleh dengan mengkalikan frekuensi jawababan dikalikan skor-nya. Contohnya untuk X2, frekuensi jawaban TS, sebanyak 8 responden sedang skor jawaban TS adalah 2, maka:

Skor Jawaban X2 untuk Jawaban $\mathrm{TS}=8 \times 2=$ 16

begitu seterusnya sehingga dapat disusun tabel di atas.

Dari tabel 6 di atas, dapat diketahui:

1) Skor terendah pada indikator X4 (dukungan dari rekan kerja untuk tetap bekerja)

2) Skor tertinggi pada indikator X1 (dukungan dari keluarga untuk tetap bekerja)

3) Skor total seluruh jawaban responden untuk variabel dukungan sosial adalah 1.052 .

Selanjutnya dihitung skor maksimal yaitu skor jika seluruh responden memberi jawaban Sangat Setuju (SS) dengan skor 5, yang perhitungannya sebagai berikut:

Skor masimal = Jumlah indikator X skor Sangat Setuju $\mathrm{X}$ Jumlah Responden $=7$ X 5 X $41=1.435$

Untuk mengetahui kategorisasi variabel dukungan sosial, selanjutnya dilakukan perbandingan skor total jawaban responden dengan skor maksimal di kalikan 100\%, yaitu $=\frac{1.052}{1.435} \times 100 \%=73,31 \%$ Hasil perbandingan tersebut yaitu $73,31 \%$ berada pada rentang 68-84\% (Lihat Tabel 2) atau berada dalam 
kategori baik.

Berdasarkan hasil perhitungan tersebut maka, variabel dukungan sosial berada dalam kategori baik.

b. Hasil Analisis Deskriptif Variabel Kecemasan Menghadapi Covid-19 (Y) Frekuensi jawaban responden dari kuesioner variabel kecemasan menghadapi Covid-19 beserta skor dari jawaban variabel kecemasan menghadapi Covid19 dapat dilihat sebagai berikut:

Tabel 7

Hasil Analisis Deskriptif Variabel Kecemasan Menghadapi Covid-19

\begin{tabular}{|c|c|c|c|c|c|c|}
\hline \multirow[t]{2}{*}{ No. } & \multicolumn{5}{|c|}{ Frekuensi Jawaban } & \multirow[t]{2}{*}{ Jumlah } \\
\hline & $\begin{array}{c}1 \\
\text { (STS) }\end{array}$ & $\begin{array}{c}2 \\
(\mathrm{TS})\end{array}$ & $\begin{array}{c}\mathbf{3} \\
\text { (RR) }\end{array}$ & $\begin{array}{c}4 \\
(\mathbf{S})\end{array}$ & $\begin{array}{c}5 \\
(\mathrm{SS})\end{array}$ & \\
\hline Y1 & 0 & 1 & 12 & 26 & 2 & 41 \\
\hline Y2 & 1 & 7 & 6 & 17 & 10 & 41 \\
\hline Y3 & 2 & 6 & 4 & 22 & 7 & 41 \\
\hline Y4 & 2 & 6 & 4 & 21 & 8 & 41 \\
\hline Y5 & 2 & 4 & 3 & 24 & 8 & 41 \\
\hline Y6 & 2 & 8 & 7 & 16 & 8 & 41 \\
\hline Y7 & 2 & 10 & 5 & 18 & 6 & 41 \\
\hline Jumlah & 11 & 42 & 41 & 144 & 49 & 287 \\
\hline \multirow[t]{2}{*}{ No. } & \multicolumn{5}{|c|}{ Skor Jawaban } & \multirow[t]{2}{*}{ Jumlah } \\
\hline & $\begin{array}{c}1 \\
\text { (STS) }\end{array}$ & $\begin{array}{c}2 \\
(\mathrm{TS})\end{array}$ & $\begin{array}{c}3 \\
(\mathbf{R R})\end{array}$ & $\begin{array}{c}4 \\
(\mathbf{S})\end{array}$ & $\begin{array}{c}5 \\
(\mathrm{SS})\end{array}$ & \\
\hline Y1 & 0 & 2 & 36 & 104 & 10 & 152 \\
\hline $\mathrm{Y} 2$ & 1 & 14 & 18 & 68 & 50 & 151 \\
\hline Y3 & 2 & 12 & 12 & 88 & 35 & 149 \\
\hline $\mathrm{Y} 4$ & 2 & 12 & 12 & 84 & 40 & 150 \\
\hline Y5 & 2 & 8 & 9 & 96 & 40 & 155 \\
\hline Y6 & 2 & 16 & 21 & 64 & 40 & 143 \\
\hline Y7 & 2 & 20 & 15 & 72 & 30 & 139 \\
\hline Jumlah & 11 & 84 & 123 & 576 & 245 & 1039 \\
\hline & & $\begin{array}{l}\tan : \\
\text { k Se } \\
=\text { San }\end{array}$ & $\begin{array}{l}\mathrm{S}=\mathrm{S} \\
\mathrm{d} ; \mathrm{RR} \\
\text { Setu }\end{array}$ & gat & $\begin{array}{l}\mathrm{KSe} \\
\mathrm{gu}\end{array}$ & $\begin{array}{l}\mathrm{u} ; \mathrm{TS}= \\
\text { Setuju; }\end{array}$ \\
\hline
\end{tabular}

Skor jawaban diperoleh dengan mengkalikan frekuensi jawababan dikalikan skor-nya. Contohnya untuk Y3, frekuensi jawaban STS, sebanyak 2 responden sedang skor jawaban STS adalah 1, maka:

Skor Jawaban Y3 untuk

Jawaban STS $=2$ X $1=2$ begitu seterusnya sehingga dapat disusun tabel di atas.
Dari tabel $7 \mathrm{di}$ atas, dapat diketahui:

1) Skor terendah pada indikator Y6 (selalu menghadapi keraguan dan ketakutan yang mengganggu)

2) Skor tertinggi pada indikator Y5 (mengalami kesulitan memusatkan pikiran)

3) Skor total seluruh jawaban responden untuk variabel kecemasan menghadapi Covid-19 adalah 1.052.

Selanjutnya dihitung skor maksimal yaitu skor jika seluruh responden memberi jawaban Sangat Setuju (SS) dengan skor 5, yang perhitungannya sebagai berikut:

Skor masimal = Jumlah indikator X skor Sangat Setuju X Jumlah Responden $\begin{array}{rlll}= & 7 \times & 5 \times 41= \\ 1.435 \text { Untuk } & & \text { mengetahui }\end{array}$ kategorisasi variabel dukungan sosial, selanjutnya dilakukan perbandingan skor total jawaban responden dengan skor maksimal di kalikan 100\%, yaitu $=\frac{1.039}{1.435} \times 100 \%=$ $72,40 \%$

Hasil perbandingan tersebut yaitu $72,40 \%$ berada pada rentang 68-84\% (Lihat Tabel 2) atau berada dalam kategori baik.

Berdasarkan hasil perhitungan tersebut maka, variabel dukungan sosial berada dalam kategori baik.

\section{Hasil Uji Asumsi Klasik}

a. Hasil Uji Normalitas

Uji normalitas dalam penelitian ini menggunakan uji Kolmogorov-Smirnov Z. Hasil uji normalitas dengan Program SPSS dikemukakan dalam tabel berikut: 
Tabel 8

Hasil Normalitas dengan KolmogorovSmirnov Z

One-Sample Kolmogorov-Smirnov Test

\begin{tabular}{|ll|r|}
\hline & & $\begin{array}{r}\text { Unstandardiz } \\
\text { ed Residual }\end{array}$ \\
\hline Normal Parameters $3 . b$ & Mean & 41 \\
& Std. Deviation & .0000000 \\
Most Extreme & Absolute & 3.68870791 \\
Differences & Positive & .125 \\
& Negative & .093 \\
Kolmogorov-Smirnov Z & -125 \\
Asymp. Sig. (2-tailed) & .803 \\
\hline \multicolumn{2}{|l|}{ a. Test distribution is Normal. } \\
b. Calculated from data.
\end{tabular}

Besarnya

nilai

Kolmogorov-Smimov dalam tabel di atas adalah 0,803 dan menunjukkan keadaan yang tidak signifikan dengan nilai derajat probabilitas signifikansi atau $p$ value $=0,539$ atau > 0,05 atau $5 \%$. Hal ini berarti Ho diterima, yang artinya bahwa data residual berdistribusi normal atau dapat dikatakan telah lolos uji normalitas.

b. Hasil Uji Autokorelasi

Akibat dari adanya autokorelasi adalah parameter yang diestimasi menjadi bias dan variannya tidak minimum, sehingga tidak efiesien. Untuk mengetahui ada tidaknya autokorelasi dapat dilakukan dengan menggunakan run test, yaitu untuk menguji apakah antar residual terdapat korelasi yang tinggi. Jika antar residual tidak terdapat hubungan korelasi maka dikatakan bahwa residual adalah acak atau random. Dari olah data SPSS uji autokorelasi terlihat seperti tabel sebagai berikut:
Tabel 9

Hasil Uji Autokorelasi dengan Run Test

\begin{tabular}{|l|r|}
\multicolumn{2}{c|}{ Runs Test } \\
\hline \multicolumn{1}{|c|}{} & $\begin{array}{r}\text { Unstandardiz } \\
\text { ed Residual }\end{array}$ \\
\hline Test Value $^{\mathrm{a}}$ & .98192 \\
Cases $<$ Test Value & 20 \\
Cases $>=$ Test Value & 21 \\
Total Cases & 41 \\
Number of Runs & 26 \\
Z & 1.270 \\
Asymp. Sig. (2-tailed) & .204 \\
\hline \multicolumn{2}{|c|}{ a. Median }
\end{tabular}

Tabel di atas menunjukkan keadaan yang tidak signifikan dengan nilai derajat probabilitas signifikansi atau $p$ value $=0,204$ atau $>0,05$ atau 5\%. Hal ini berarti $\mathrm{Ho}$ diterima, yang artinya bahwa residual tidak random atau tidak terjadi autokorelasi.

\section{c. Hasil Uji Multikolinearitas}

Multikolinieritas adalah suatu keadaan di mana salah satu atau lebih variabel independen dapat dinyatakan sebagai kombinasi linier dari variabel independen lainnya. Cara yang digunakan untuk mendeteksi ada tidaknya multikolinieritas adalah dengan melakukan regresi antar variabel penjelas. Jika signifikan berarti terdapat multikolinieritas. Untuk menguji multikolinieritas degunakan vasilitas yang disediakan SPSS yaitu dengan melihat nilai VIF dari variabel. Jika nilai VIF lebih rendah dari 10, maka dapat disimpulkan bahwa tidak ada multikolinieritas yang serius antara variabel independen dalam model. Tabel berikut menunjukkan hasil uji 
multikolinieritas yang dapat ditabelkan sebagai berikut:

Tabel 10

Ringkasan Hasil Pengujian Multikolinieritas dengan

Menggunakan Varian

Inflation Factor (VIF)

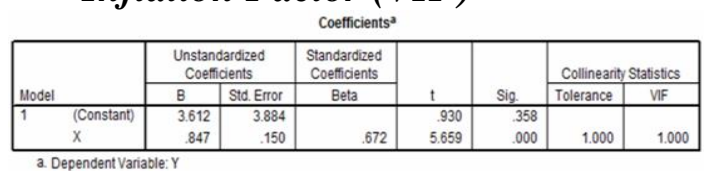

Dengan melihat nilai VIF dalam tabel di atas dapat diketahui bahwa variabel tidak mengandung adanya gejala multikolinieritas karena mempunyai nilai VIF $=1,00$ yang lebih rendah dari 10. Hal ini menunjukkan model regresi tersebut lolos uji multikolinieritas.

\section{Hasil Analisis Product Moment} Pearson

Hasil analisis Product Moment Pearson dengan menggunakan bantuan program SPSS Ver.22 dapat dilihat sebagai berikut:

Tabel 11

Hasil Analisis Product Moment Pearson

\begin{tabular}{|c|c|c|c|}
\hline \multicolumn{4}{|c|}{ Correlations } \\
\hline & & $\begin{array}{c}\text { Dukungan } \\
\text {.Sosial }\end{array}$ & $\begin{array}{c}\text { Kecemasang.Mengha } \\
\text { dapi.Covid19 }\end{array}$ \\
\hline Dukungan.Sosial & $\begin{array}{l}\text { Pearso } \\
\mathrm{n} \\
\text { Correl } \\
\text { ation }\end{array}$ & 1 & $-.672^{* *}$ \\
\hline & $\begin{array}{l}\text { Sig. } \\
(2- \\
\text { tailed) }\end{array}$ & & .000 \\
\hline & $\mathrm{N}$ & 41 & 41 \\
\hline $\begin{array}{l}\text { Kecemasang.Mengha } \\
\text { dapi.Covid19 }\end{array}$ & $\begin{array}{l}\text { Pearso } \\
\mathrm{n} \\
\text { Correl } \\
\text { ation }\end{array}$ & $-.672^{* *}$ & 1 \\
\hline & $\begin{array}{l}\text { Sig. } \\
(2- \\
\text { tailed) }\end{array}$ & .000 & \\
\hline & $\mathrm{N}$ & 41 & 41 \\
\hline
\end{tabular}

Berdasarkan hasil analisis korelasi tersebut di atas dapat dilihat bahwa $p$ value (sig.) bernilai $0,000<0,05(5 \%)$. Hal ini berarti ada hubungan antara dukungan sosial dengan kecemasan menghadapi Covid-19, sehingga dapat disimpulkan bahwa $\mathrm{H}_{1}$ terbukti yang artinya dukungan sosial mempunyai hubungan yang negatif dan signifikan terhadap kecemasan menghadapi Covid-19.

6. Hasil Analisis Regresi

Hasil analisis regresi dengan menggunakan bantuan program SPSS Ver.22 dapat dilihat sebagai berikut:

Tabel 12

Hasil Analisis Regresi

Coefficients $^{\mathrm{a}}$

\begin{tabular}{|c|c|c|c|c|c|}
\hline \multirow[b]{2}{*}{ Model } & \multicolumn{2}{|c|}{$\begin{array}{l}\text { Unstandardize } \\
\text { d Coefficients }\end{array}$} & \begin{tabular}{|c} 
Standardize \\
$\mathrm{d}$ \\
Coefficient \\
$\mathrm{s}$
\end{tabular} & & \\
\hline & B & $\begin{array}{l}\text { Std. } \\
\text { Error }\end{array}$ & Beta & $\mathrm{t}$ & Sig. \\
\hline (Constant) & 3.612 & 3.884 & & .930 & $\begin{array}{r}.35 \\
8\end{array}$ \\
\hline $\begin{array}{l}\text { Dukungan.Sosi } \\
\text { al }\end{array}$ & -.847 & .150 & .672 & $\begin{array}{r}5.65 \\
9\end{array}$ & $\begin{array}{r}.00 \\
0\end{array}$ \\
\hline
\end{tabular}

Berdasarkan hasil analisis regresi tersebut di atas dapat dilihat bahwa $p$ value (sig.) bernilai 0,000 $<0,05(5 \%)$. Selain itu juga menunjukkan koefisien regresi 0,847, Hal ini berarti dukungan sosial berpengaruh negatif dan signifikan terhadap kecemasan menghadapi Covid-19, sehingga dapat disimpulkan bahwa $\mathrm{H}_{2}$ terbukti. Berpengaruh negatif dan signifikan artinya jika dukungan sosial meningkat, maka akan menyebabkan kecemasan menghadapi Covid-19 akan menurun.

Untuk melihat kontribusi variabel dukungan sosial (X) 
terhadap variabel kecemasan menghadapi Covid-19 digunakan uji koefisien determinasi sebagai berikut:

Tabel 13

\section{Hasil Analisis Koefisien Determinasi} Model Summary

\begin{tabular}{|l|r|r|r|r|}
\hline Model & \multicolumn{1}{|c|}{$\mathrm{R}$} & $\mathrm{R}$ Square & $\begin{array}{c}\text { Adjusted R } \\
\text { Square }\end{array}$ & $\begin{array}{c}\text { Std. Error } \\
\text { of the } \\
\text { Estimate }\end{array}$ \\
\hline 1 & $.672^{\mathrm{a}}$ & .451 & .437 & 3.73570 \\
\hline
\end{tabular}

a. Predictors: (Constant), Dukungan.Sosial

Dari tampilan output SPSS hasil analisis koefisien determinasi tersebut di atas, besarnya adjusted $\mathrm{R}^{2}$ adalah 0,437 atau $43,7 \%$. Hal ini berarti $43,7 \%$ variabel kecemasan menghadapi Covid-19 dijelaskan oleh variabel dukungan sosial. Sedangkan sisanya 56,3\% (100\%43,7\%) dijelaskan oleh sebab-sebab yang lain di luar model yang tidak diteliti.

\section{H. Kesimpulan dan Saran}

\section{Kesimpulan}

Berdasarkan rumusan masalah, tujuan penelitian dan hipotesis penelitian serta hasil penelitian dan pembahasan, maka dapat disimpulkan hal-hal sebagai berikut:

a. Ada hubungan antara dukungan sosial dengan kecemasan menghadapi Covid-19.

b. Dukungan sosial berrpengaruh negatif dan signifikan terhadap kecemasan menghadapi Covid19. Berpengaruh negatif dan signifikan artinya jika dukungan sosial meningkat, maka akan menyebabkan kecemasan menghadapi Covid19 akan menurun. Variabel kecemasan menghadapi Covid19 dijelaskan oleh variabel dukungan sosial sebesar 43,7\%, sedangkan sisanya $56,3 \%$ dijelaskan oleh sebab-sebab yang lain di luar model yang tidak diteliti.

\section{Saran}

Berdasarkan kesimpulan di atas, maka saran-saran yang dapat diberikan melalui hasil penelitian ini baik kepada perusahan, karyawan maupun untuk pengembangan penelitian yang lebih lanjut adalah sebagai berikut:

a. Mengingat skor terendah variabel dukungan sosial ada pada indikator dukungan dari rekan kerja untuk tetap bekerja, maka disarankan kepada seluruh karyawan dan manajemen CV. Citra Jaya Banjarbaru untuk saling memberi dukungan agar seluruh karyawan tetap semangat dalam bekerja.

b. Mengingat sektor terendah variabel kecemasan menghadapi Covid-19 aada pada indikator selalu menghadapi keraguan dan ketakutan yang mengganggu, maka disarankan pada seluruh karyawan CV. Citra Jaya Banjarbaru untuk tetap bekerja dengan tenang yang penting selalu mengikuti protokol kesehatan.

\section{Referensi}

Abro, A.H., M.C.A. Klein, and S.A. Tabatabaei. 2015. "An AgentBased Model for the Role of Social Support in Mood Regulation". Springer International Publishing Switzerland.

Adnyaswari, Nyoman Adinda dan I Gusti Ayu Dewi Adnyani. 2017. "Pengaruh Dukungan Sosial dan Burnout terhadap Kinerja Perawat Rawat Inap RSUP Sanglah". Jurnal Manajemen Unud. Vol. 6. No. 5.

Calhoun, F \& Acocella, J. 2015. Psikologi tentang Penyesuaian dan Hubungan. Kemanusiaan. Semarang: IKIP Semarang. 
Chou, Paul. 2015. "The Effects of Workplace Social Support on Employee's Subjective WellBeing". European Journal of Business and Management. Vol. 7. No. 6.

Edelmann, Robert J. 2016. Interpersonal Conflicts at Work (Edisi Revisi) Yogyakarta: Kanisius.

García-Herrero, Susana, Jose R. LopezGarcia, Sixto Herrera, Ignacio Fontaneda, Sonia Muñoz Báscones, and Miguel A. Mariscal. 2017. "The Influence of Recognition and Social Support on European Health Professionals' Occupational Stress: A Demands-Control-Social Support-Recognition Bayesian Network Model". Hindawi BioMed Research International.

Ghozali, Imam. 2012. Aplikasi Analisis Multivariate Dengan Program IBM SPSS. 20. Semarang: Penerbit Universitas Diponegoro.

Hamouche, Salima. 2020. "Covid-19 and Employees' Mental Health: Stressors, Moderators And Agenda For Organizational Actions". Emerald Open Research. Vol. 2. No. 15.

Iskandarsyah, A \& Yudiana, W. 2020. "Informasi Covid-19, Perilaku Sehat Dan Kondisi Psikologis di Indonesia". Laporan Survei. Fakultas Psikologi Universitas Padjajaran.

Iswanto, Ferry dan Ike Agustina. 2016. "Peran Dukungan Sosial di Tempat Kerja Terhadap Keterikatan Kerja Karyawan". Jurnal Mediapsi. Vol. 2. No. 2.

Johnson, David \&Roger Johnson. 2015. Leading the Cooperative School. (Terjemanahan Edina). MN: Interaction Book Company.

Li, S., Wang, Y., Xue, J., Zhao, N. dan Zhu, T. 2020. "The Impact of COVID-19 Epidemic Declaration on Psychological Consequences: A Study on Active Weibo Users". International Journal of
Environment Research and Public Health. Vol. 3. No. 2.

De Clarq, Linda. 2017. Tingkah Laku Abnormal, dari sudut pandang perkembangan. Jakarta: PT. Grasindo.

Nahum-Shani, Inbal, Peter A. Bamberger and Samuel B. Bacharach. 2015. "Social Support and Employee Well-Being: The Conditioning Effect of Perceived Patterns of Supportive Exchange". J Health Soc Behav. Vol. 52. No. 1.

Nevid, S.F, Rathus, A.S. dan Greene, B. 2018. Psikologi Abnormal. Jakarta: Erlangga.

Nichols, K., \& Jenkinson, J. 2015. Leading a support group. London: Open University Press.

Purnamarini, D. P., Setiawan, T. I., dan Hidayat, D. R. 2016. "Pengaruh Terapi Expressive Wiriting Terhadap Penurunan Kecemasan Saat Ujian". Bimbingan Konseling. Vol. 3. No. 2.

Putra, Putu Surya Parama dan Luh Kadek Pande Ary Susilawati. 2018. "Hubungan antara Dukungan Sosial dan Self Efficacy dengan Tingkat Stres pada Perawat di Rumah Sakit Umum Pusat Sanglah". Jurnal Psikologi Udayana. Vol.5. No.1.

Rosenberg, M. dan Caplan, 2016. Social Psychology of Self Concept. Illinois: Harlan Davidson, Inc.

Sarafino. 2015. Health Psychology Biopsychosocial Interaction. USA: John Wiley \& Sons.

Sears, David. O. dan Freedman, J.L. 2017. Psikologi Sosial. Jakarta: Erlangga.

Sekaran, Uma. 2013. Research Metods for Business: A Skill Building Approach. New York: John Willey $\&$ Sons.

Stapleton, Jessie N., Curt L. Lox, Jennifer I. Gapin, Jonathan C. Pettibone dan Karen L. Gaudreault. 2015. "Social Support as A Stage Specific Correlate of Physical Activity". Graduate Journal of Sport, 
Exercise and Physical Education Research. Vol. 3.

Sugiyono. 2017. Metodologi Penelitian Bisnis. Bandung: AlfaBeta.

Syafrida dan Ralang Hartati, 2020. "Bersama Melawan Virus Covid 19 di Indonesia". Jurnal Sosial dan Budaya. Vol. 7. No. 6.

Wang, C., Pan, R., Wan, X., Tan, Y, Xu, L., Ho,C.S. dan Roger C. Ho, R.C. 2020. "Immediate Psychological Responses and Associated Factors during the Initial Stage of the 2019 Coronavirus Disease (COVID-19) Epidemic among the General Population in China". International.Journal of Environment Research and Public Health. Vol. 4. No. 1.

Xiao, Han, Yan Zhang, Desheng Kong, Shiyue Li dan Ningxi Yang. 2020. "The Effects of Social Support on Sleep Quality of Medical Staff Treating Patients with Coronavirus Disease 2019 (Covid 19) in January and February 2020 in China". Medical Science Monitor Journal, e-ISSN 1643-3750.

Zimet, G. D., Dahlem, N. W., Zimet, S. G., \& Farley, G. K. 2014. "The Multidimensional Scale of Perceived Social Support". Journal of Personality Assessment. Vol. 52. No. 1. 